\title{
The effect on the lanthanide luminescence of structurally simple Eu(III) cyclen complexes upon deprotonation of metal bound water molecules and amide based pendant arms
}

\author{
Sally E. Plush, ${ }^{* a, b}$ Naomi A. Clear, ${ }^{a}$ Joseph P. Leonard, ${ }^{a}$ Ann-Marie Fanning ${ }^{a}$ and Thorfinnur Gunnlaugsson $* a$ \\ Received 9th November 2009, Accepted 23rd January 2010 \\ First published as an Advance Article on the web 5th March 2010 \\ DOI: 10.1039/b923383k
}

A series of substituted 1,4,7,10-tetraazacylcododecane ligands 1-4, possessing sensitizing nitrobenzene or naphthalene antennae, as one of the amide pendant arms, and their complexes with europium(III) were synthesised. The protonation constants and the metal ion stability constants of two of these ligands were determined by potentiometric titration. The $\mathrm{p} K_{\mathrm{a}}$ of the water molecules coordinated to the complexed metal ion were determined by both luminescent and potentiometric measurements. The luminescence $\mathrm{pH}$ dependence of a further three $\mathrm{Eu}$ (III) complexes, 5-7, which lack any antennae, were also studied with the aim of gaining a better understanding of the role of the metal bound water molecules in the luminescence properties of such complexes upon direct excitation of the lanthanide ion. The results from these luminescent measurements demonstrate that the $\mathrm{Eu}(\mathrm{III})$ emission was significantly modulated as a function of $\mathrm{pH}$ for all the complexes, which we assigned to changes occurring in the coordination environment of the ion within the cyclen system, caused by deprotonation of metal bound water molecules and/or deprotonation of pendent amide arms.

\section{Introduction}

Due to the unique magnetic, luminescent and coordination properties of the lanthanides, they have become extensively employed in the synthesis and study of novel coordination networks ${ }^{1}$ and metal directed synthesis, ${ }^{2}$ in functional supramolecular structures ${ }^{3}$ and self-assemblies. ${ }^{4}$ Their use in luminescent sensing ${ }^{5}$ and imaging technology, ${ }^{6-8}$ and as contract agents for MRI is also very well established. ${ }^{9}$ They have also been used for mimicking the function of biological species, such as metallo based enzymes. ${ }^{10,11}$ While the properties of the lanthanide ion itself is central to all of these functions, the direct, or synergetic, actions of metal bound water molecules (usually mono- or di-aqua species) in such structures is also important to the overall function of such complexes. ${ }^{12}$ One of the most commonly used ligands for forming such functional lanthanide complexes/devices is cyclen (1,4,7,10-tetraazacyclododecane). ${ }^{13}$ The cyclen structure can be relatively easily synthetically modified, to incorporate a variety of pendant arm functionalities, which, upon complexation to lanthanides, give structures with one or two metal bound water molecules. ${ }^{14-16}$ We have employed such structures extensively in our research endeavours as catalysts for phosphodiester hydrolysis and as luminescent probes, and we have demonstrated that their function/activity is usually highly $\mathrm{pH}$ dependent. ${ }^{17}$ For instance, we, and others, have shown that the emission of cyclen based $\mathrm{Eu}$ (III) and $\mathrm{Tb}$ (III) complexes can be tuned as a function of $\mathrm{pH}$ in systems possessing sensitizing antenna conjugated to the cyclen macrocycle via a carboxylamide linkage. ${ }^{18-20}$ However, to

${ }^{a}$ School of Chemistry, Centre of Synthesis and Chemical Biology, University of Dublin, Trinity College Dublin, D2, Ireland

${ }^{b}$ Sansom Institute, School of Pharmacy and Medical Sciences, University of South Australia, Adelaide, SA, 5000,Australia.E-mail: gunnlaut@ tcd.ie,Sally.Plush@unisa.edu.au the best of our knowledge, a dedicated study into the effect of $\mathrm{pH}$ on the luminescent properties of such simple lanthanide cyclen complexes, that do not have proton acceptors, e.g. heterocycles or amino functionalities, has not been carried out in any detail to date.

With this in mind, we set out to investigate these effects by synthesizing a series of novel cyclen derivatives $\mathbf{1 - 4}$ as well as investigating three known cyclen based structures, 5-7, which lack any sensitizing antennae, Fig. 1. Our aim was to attempt to correlate results from potentiometric $\mathrm{pH}$ titrations with that of lanthanide luminescent $\mathrm{pH}$ titrations for these complexes, and gain understanding of the effect that metal bound water molecules,
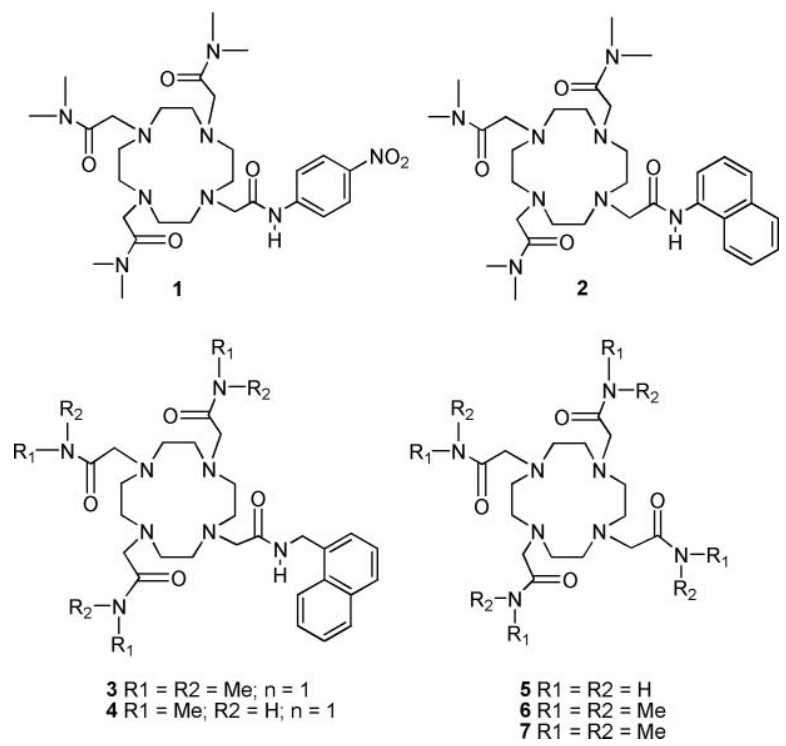

Fig. 1 Compounds 1-7 employed in the current study. 
as well as pendant arms, possessing protonating/deprotonating amide functional groups, have on the photophysical properties of these structurally simple complexes. The results obtained should allow for the accurate assignment of the various species in solutions, and correlate these to the changes in luminescence properties.

\section{Results and discussion}

\section{Synthesis and characterization of 1-7}

We have previously employed the naphthalene chromophore as a sensitizing antenna in lanthanide luminescent complexes for use as luminescent sensors for anions as well as in the development of lanthanide mediated self-assemblies. ${ }^{15}$ Herein, examples 2-4 were developed by incorporating the naphthalene antenna through a pendant amide linkage, either via a methylene spacer or as part of the amide functionality. All the complexes were designed so that they would give rise to an eight coordinate environment around the lanthanide ion, which should ensure that each metal would possess a single metal bound water molecule, giving an overall nine coordinate complex. These structures should provide us with two possible scenarios, where in the case of $\mathbf{2}$, the aryl amide possesses an acidic amide proton which can be deprotonated leading to concomitant modulation in the lanthanide luminescence, and in the cases of $\mathbf{3}$ and $\mathbf{4}$, the antenna would not be expected to be as sensitive to changes in $\mathrm{pH}$. Hence, for $\mathbf{3}$ and $\mathbf{4}$, any significant luminescent changes observed as a function of $\mathrm{pH}$ should only be as a direct consequence of deprotonation of metal bound water molecules.

Compound $\mathbf{1}$ was also investigated for comparison, as the presence of the 4-nitro moiety in the aryl antenna would make the amide proton even more acidic and hence deprotonation at lower $\mathrm{pH}$ would be expected. The synthesis of ligands 1, 5-7 and Eu5-7 are established and reported elsewhere. ${ }^{4,21,22}$ The synthesis of ligands 2-4 was achieved as shown in Scheme 1. The $\alpha$ chloroamide compounds $\mathbf{8}$ and $\mathbf{9}$ were prepared from the reaction of the primary amine derivatives with triethylamine and either chloroacetyl chloride or chloroacetic anhydride, respectively, in $\mathrm{DCM}$ at $0{ }^{\circ} \mathrm{C}$. Compound $\mathbf{8}$ was then reacted with the trisubstituted cyclen derivative $\mathbf{1 0}$ in the presence of $\mathrm{Cs}_{2} \mathrm{CO}_{3}$ in DMF to yield ligand 2. Under similar conditions compound 9 was reacted with either the tri-substituted cyclen derivates $\mathbf{1 0}$ or 11 to yield ligands 3 or $\mathbf{4}$, respectively. The Eu(III) complexes of 1 and 2 were made by reacting one equivalent of $\mathrm{Eu}\left(\mathrm{ClO}_{4}\right)_{3}$ with the ligand in $\mathrm{MeOH}$ at room temperature, giving complexes, Eu1 and Eu2, respectively. In compounds 2-4, the naphthyl-based antenna, has $T_{1}$ energy states lower than $20000 \mathrm{~cm}^{-1}$, as this prevents the effective population of $\mathrm{Tb}$ (III) excited states (due to quenching by $\mathrm{O}_{2}$ ) and hence, only the Eu(III) complexes were made. The Eu(III) complexes of $\mathbf{3}$ and $\mathbf{4}$ were made by refluxing one equivalent of $\mathrm{Eu}\left(\mathrm{CF}_{3} \mathrm{SO}_{3}\right)_{3}$ with the ligand in $\mathrm{CH}_{3} \mathrm{CN}$, giving complexes, Eu3 and Eu4, respectively. All the Eu(III) complexes gave rise to significant chemical shifts in the ${ }^{1} \mathrm{H}$ NMR spectra due to the presence of the paramagnetic Eu(III) ion. The characterization of these ligands and their corresponding Eu(III) complexes is given in the experimental section.

The hydration state, or the number of metal bound water molecules was also determined, by measuring the lifetimes of the deactivation of the Eu(III) excited state in $\mathrm{H}_{2} \mathrm{O}$ and $\mathrm{D}_{2} \mathrm{O}$ respectively. ${ }^{22}$ For Eu2, Eu3 and Eu4, these were determined as $1.25,1.11$ and $1.55( \pm 0.3)$, respectively, indicating that all of these complexes possessed a single metal bound water molecule. For Eu4, a $q$ value of 1.55 is quite high, which might indicate that a second water molecule might be partially coordinating. Similarly, complexes Eu1 and Eu5-7 were also shown to have single metal water bound molecule. Having successfully synthesized the above compounds we next undertook the potentiometric analysis of ligands $\mathbf{1}$ and $\mathbf{2}$ and their corresponding Eu(III) complexes, with the aim of determining the $\mathrm{p} K_{\mathrm{a}}$ of these metal bound water molecules.

\section{Potentiometric determination of $\mathrm{p} K_{\mathrm{a}}$}

The $\mathrm{p} K_{\mathrm{a}}$ 's of the protonated ligands 1, Fig. 2, and 2 were determined in 50:50 water-methanol $(\mathrm{v} / \mathrm{v})$ solution to ensure complete solubilization. The ligands were acidified with $\mathrm{HClO}_{4}$ and titrated against $\mathrm{NEt}_{4} \mathrm{OH}$ under argon at $25^{\circ} \mathrm{C}$ with $I=0.1 \mathrm{M}$ $\left(\mathrm{NEt}_{4} \mathrm{ClO}_{4}\right)$. The logarithm of the stepwise protonation constants for ligands $\mathbf{1}$ and $\mathbf{2}$, obtained from the mathematical treatment of their respective potentiometric titration data are represented in Table 1; the conditions for each titration are listed below the table. Four $\mathrm{p} K_{\mathrm{a}}$ 's were determined for the protonated ligands $\mathbf{1}$ and $\mathbf{2}$ and these were assigned to the protonated macrocyclic amines. The incorporation of a naphthyl pendant arm in comparison to a nitro phenyl pendant arm had only a very small effect on the protonation constants of the ligands. The nitro phenyl pendant arm causes a slight increase in the overall acidity of the ligand in comparison to the naphthyl pendant arm. This can be attributed to differences in steric bulk of the two ligands, which alters the hydrophobicity of the system.
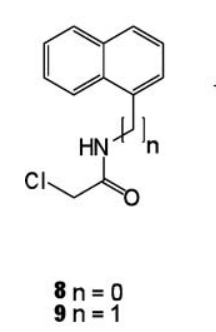

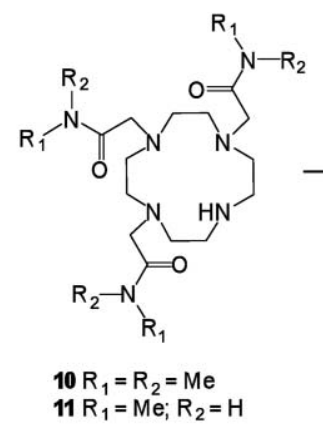

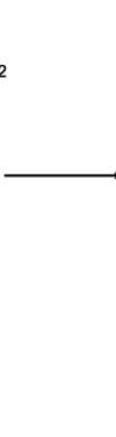

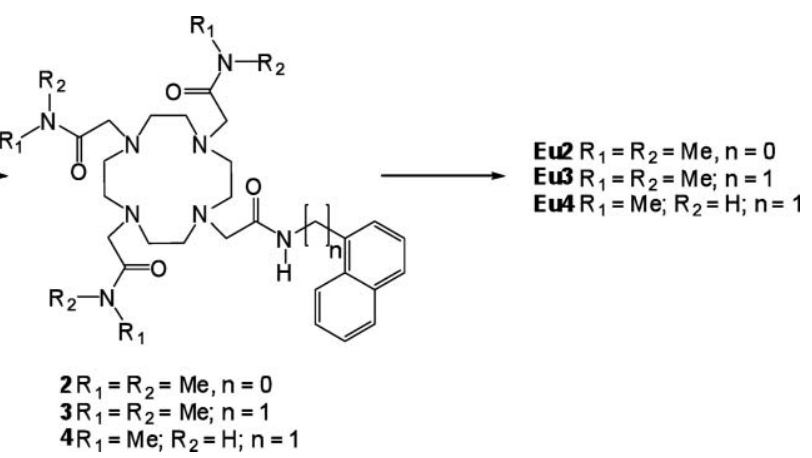

Scheme 1 Synthesis of compounds 2-4 and their corresponding Eu(III) complexes. 
Table 1 Results from the potentiometric titration of $\mathbf{1}$ and $\mathbf{2}$

\begin{tabular}{lll}
\hline $\mathrm{p} K_{\mathrm{a}}$ & $\mathbf{1}$ & $\mathbf{2}$ \\
\hline$[\mathrm{L}]\left[\mathrm{H}^{+}\right] /\left[\mathrm{H}(\mathrm{L})^{+}\right]$ & $8.52 \pm 0.04$ & $9.63 \pm 0.03$ \\
{$[\mathrm{LH}]\left[\mathrm{H}^{+}\right] /\left[\mathrm{H}_{2}(\mathrm{~L})^{2+}\right]$} & $7.32 \pm 0.04$ & $8.17 \pm 0.05$ \\
{$\left[\mathrm{LH}_{2}\right]\left[\mathrm{H}^{+}\right] /\left[\mathrm{H}_{3}(\mathrm{~L})^{3+}\right]$} & $6.85 \pm 0.06$ & $6.99 \pm 0.06$ \\
{$\left[\mathrm{LH}_{3}\right]\left[\mathrm{H}^{+}\right] /\left[\mathrm{H}_{4}(\mathrm{~L})^{4+}\right]$} & $2.80 \pm 0.09$ & $2.63 \pm 0.06$
\end{tabular}

$[1]=5.60 \times 10^{-4} \mathrm{~mol} \mathrm{dm}^{-3},\left[\mathrm{H}^{+}\right]=4.40 \times 10^{-4} \mathrm{~mol} \mathrm{dm}^{-3},\left[\mathrm{NEt}_{4} \mathrm{OH}\right]=$ $0.105 \mathrm{~mol} \mathrm{dm}^{-3} ;[2]=4.33 \times 10^{-4} \mathrm{~mol} \mathrm{dm}{ }^{-3},\left[\mathrm{H}^{+}\right]=9.01 \times 10^{-4} \mathrm{~mol} \mathrm{dm}^{-3}$, $\left[\mathrm{NEt}_{4} \mathrm{OH}\right]=0.098 \mathrm{~mol} \mathrm{dm}^{-3}$. All at $25^{\circ} \mathrm{C}$.

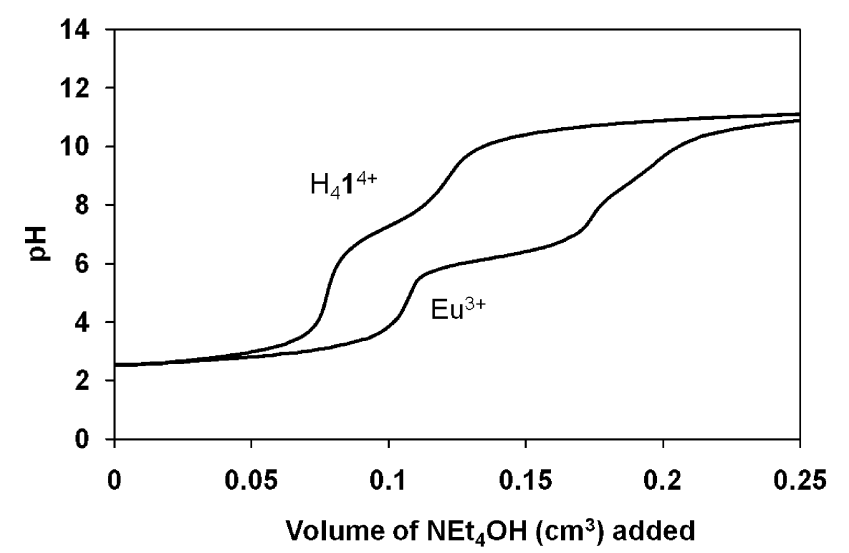

Fig. 2 Titration curve for protonated ligand 1 formed in solution where $[\mathbf{1}]=5.60 \times 10^{-4} \mathrm{~mol} \mathrm{dm}^{-3}$ and $\left[\mathrm{H}^{+}\right]=4.40 \times 10^{-3} \mathrm{~mol} \mathrm{dm}^{-3}, 25^{\circ} \mathrm{C}$ with $I=$ $0.1 \mathrm{M}\left(\mathrm{NEt}_{4} \mathrm{ClO}_{4}\right), 50: 50(\mathrm{v} / \mathrm{v}) \mathrm{MeOH}-\mathrm{H}_{2} \mathrm{O}$. The titration curve is also shown for the same solution, except that $\left[\mathrm{Eu}^{3+}\right]=1.00 \times 10^{-3} \mathrm{~mol} \mathrm{dm}^{-3}$ is also present. Titrant $\left[\mathrm{NEt}_{4} \mathrm{OH}\right]=0.105 \mathrm{~mol} \mathrm{dm}^{-3}$.

We also determined the $\mathrm{p} K_{\mathrm{a}}$ 's of ligands 5-7 at $25{ }^{\circ} \mathrm{C}$ with $I=$ $0.1 \mathrm{~mol} \mathrm{dm}^{-3}\left(\mathrm{NEt}_{4} \mathrm{ClO}_{4}\right)$ in $100 \% \mathrm{H}_{2} \mathrm{O}$. However, we were only able to determine three $\mathrm{p} K_{\mathrm{a}}$ 's accurately for each of the ligands. For 5, which possesses primary amides these were $10.71 \pm 0.02$, $8.93 \pm 0.02$ and $6.35 \pm 0.03$. Whereas, for 6 , possessing secondary amides, the three $\mathrm{p} K_{\mathrm{a}}$ 's were determined as: $9.13 \pm 0.04,5.60 \pm$ 0.01 and $2.24 \pm 0.01$, and for 7 , with tertiary amides, these were determined as $9.50 \pm 0.07,6.34 \pm 0.03$ and $2.93 \pm 0.03$, respectively. The exact assignment of these $\mathrm{p} K_{\mathrm{a}}$ 's is difficult based only on this experimental data. However, based on analysis of similar systems ${ }^{23}$ it is anticipated that for $\mathbf{6}$ and $\mathbf{7}$ the three $\mathrm{p} K_{\mathrm{a}}$ 's determined may be attributed to the protonation of the cyclen based amines. With the fourth cyclen based amine occurring at a very acidic $\mathrm{pH}$. Whereas for 5 , only two of the $\mathrm{p} K_{\mathrm{a}}$ 's would be attributed to the cyclen based amines (third and fourth being too acidic for measurement); the other $\mathrm{p} K_{\mathrm{a}}$ is most likely to be from one of the primary amide pendant arms.

\section{Evaluating the formation of Eu1 and Eu2 by potentiometric titrations}

The complexation constants and stoichiometry of the Eu(III) complexes of $\mathbf{1}$ and $\mathbf{2}$, were determined using the above method, in the presence of Eu(III), Table 2. The metal ion competes with protons in the acidic media for ligand coordination sites; this alters the $\mathrm{pH}$ of the solution and results in a different titration curve as can be seen for 1 in Fig. 2. The basicity of the donor atoms is known to directly influence the stability of the complex, and as already
Table 2 Results form the potentiometric titration of $\mathbf{1}$ and $\mathbf{2}$ with Eu(III)

\begin{tabular}{lll}
\hline Equilibrium Quotient & $\mathbf{1}$ & $\mathbf{2}$ \\
\hline$\left[\mathrm{Eu}(\mathrm{L})^{3+}\right] /\left[\mathrm{Eu}^{3+}\right][\mathrm{L}]$ & $20.59 \pm 0.02$ & $20.89 \pm 0.09$ \\
{$\left[\left[\mathrm{Eu}\left(\mathrm{LH}_{-1}\right)^{2+}\right]\left[\mathrm{H}^{+}\right] /\left[\mathrm{Eu}(\mathrm{L})^{3+}\right]\right.$} & $6.55 \pm 0.05$ & $6.53 \pm 0.09$ \\
{$\left[\mathrm{Eu}\left(\mathrm{LH}_{-2}\right)^{+}\right]\left[\mathrm{H}^{+}\right] /\left[\mathrm{Eu}\left(\mathrm{LH}_{-1}\right)^{2+}\right]$} & $7.97 \pm 0.03$ & $8.54 \pm 0.09$
\end{tabular}

$[1]=5.60 \times 10^{-4} \mathrm{~mol} \mathrm{dm}^{-3},\left[\mathrm{Eu}^{3+}\right]=1.00 \times 10^{-3} \mathrm{~mol} \mathrm{dm}^{-3},\left[\mathrm{H}^{+}\right]=4.40 \times$ $10^{-3} \mathrm{~mol} \mathrm{dm}^{-3},\left[\mathrm{NEt}_{4} \mathrm{OH}\right]=0.105 \mathrm{~mol} \mathrm{dm}{ }^{-3} \cdot[2]=6.72 \times 10^{-4} \mathrm{~mol} \mathrm{dm}^{-3}$, $\left[\mathrm{Eu}^{3+}\right]=1.00 \times 10^{-3} \mathrm{~mol} \mathrm{dm}^{-3},\left[\mathrm{H}^{+}\right]=9.01 \times 10^{-3} \mathrm{~mol} \mathrm{dm}^{-3},\left[\mathrm{NEt}_{4} \mathrm{OH}\right]=$ $0.0986 \mathrm{~mol} \mathrm{dm}^{-3}$. All at $25^{\circ} \mathrm{C}$.

mentioned, this is affected by the presence and type of pendant arm. The ligands presented here have been designed to coordinate lanthanide ions in an octadentate coordination "cage", leaving the lanthanide ion coordinatively unsaturated. Hence, the remaining site is then occupied by a water molecule. Two $\mathrm{p} K_{\mathrm{a}}$ values for the metal ion complexes of ligands $\mathbf{1}$ and $\mathbf{2}$ with $\mathrm{Eu}^{3+}$ were determined. From the potentiometric titrations alone the exact assignment of these $\mathrm{p} K_{\mathrm{a}}$ values is not possible. However, it can be anticipated that one of these $\mathrm{p} K_{\mathrm{a}}$ values could be assigned to the deprotonation of the metal bound water molecule.

It has been previously reported by us and others that the incorporation of an electron withdrawing group in a position adjacent to the amide bearing the donor oxygen lowers the $\mathrm{p} K_{\mathrm{a}}$ of the nitrogen in the amide. ${ }^{15,16}$ Therefore, it can be assumed that the other $\mathrm{p} K_{\mathrm{a}}$ corresponds with the deprotonation of the nitrogen in the bonding amide. The speciation distribution diagram for the titration of 1 with $\mathrm{Eu}(\mathrm{III})$ as a function of $\mathrm{pH}$ is shown in Fig. 3, and demonstrates three possible $\mathrm{pH}$ windows that could modulate the luminescence of the complex. The slight variation in the $\mathrm{p} K_{\mathrm{a}}$ values for the two complexes, Eu1 and Eu2, may be attributed to the differences in steric bulk. The determination of the stability constants for 5-7 was also attempted, however, on all occasions precipitation occurred under potentiometric titration conditions. The formation of insoluble metal hydroxide species at the high concentrations required for potentiometry is commonly observed for such cyclen based lanthanide complexes. ${ }^{11}$

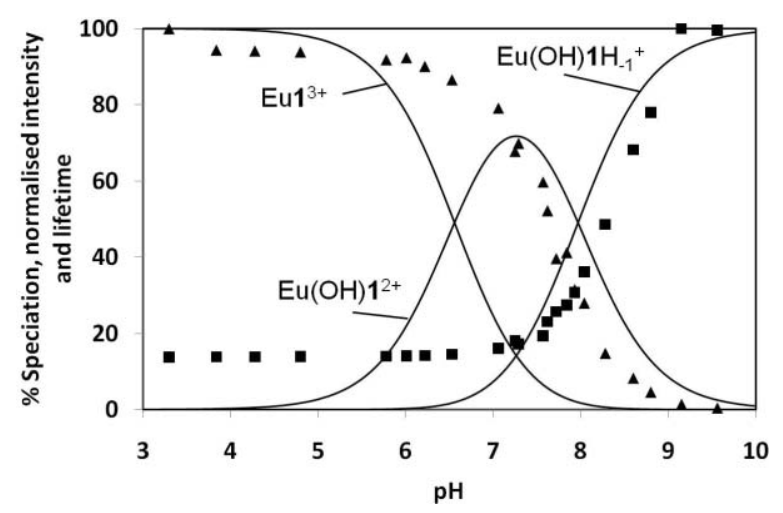

Fig. 3 Speciation variation of Eu1 showing the species present in 50:50 $(\mathrm{v} / \mathrm{v}) \mathrm{MeOH}-\mathrm{H}_{2} \mathrm{O}$ at various $\mathrm{pH}$ in which $[1]=5.60 \times 10^{-4} \mathrm{~mol} \mathrm{dm}^{-3}$, $\left[\mathrm{Eu}^{3+}\right]=1.00 \times 10^{-3} \mathrm{~mol} \mathrm{dm}^{-3}, 25^{\circ} \mathrm{C}$ with $I=0.1 \mathrm{M}\left(\mathrm{NEt}_{4} \mathrm{ClO}_{4}\right)$. Speciation is shown relative to the total concentration of $\mathbf{1}$. The normalized change in lifetime (ם) and the $\mathrm{Eu}^{3+}$ emission intensity at $616 \mathrm{~nm}(\mathbf{\Lambda})$ of the complex Eu1 with $\mathrm{pH}$ is also shown. 


\section{Photophysical investigations as a function of pH of ligands 1 and 2 and their $\mathbf{E u}(\mathrm{III})$ complexes}

The lanthanide ions are considered to be photophysically inert with low molar absorptivity due to Laporte forbidden $\mathrm{f}-$ f transitions. While the lanthanide excited state can be formed by direct excitation, then these are often generated indirectly by using a sensitizing chromophore, or an antenna; these being the nitrobenzene and the naphthalene in ligands $\mathbf{1 - 4}$.

The $\mathrm{Eu}^{3+}$ complexes Eu1 and Eu2, were excited at their absorption maxima $298 \mathrm{~nm}$ and $280 \mathrm{~nm}$, respectively. On both occasions, sensitized luminescence was observed from the metal ion centre in these complexes in 50:50 (v/v) $\mathrm{MeOH}-\mathrm{H}_{2} \mathrm{O}$. The $\mathrm{Eu}^{3+}$ emission spectra recorded for Eu1 in acidic media, following excitation of the nitrophenyl moiety at $298 \mathrm{~nm}$, displayed five bands arising from the deactivation of ${ }^{5} \mathrm{D}_{\mathrm{o}}$ level to ${ }^{7} \mathrm{~F}_{J}(J=1$, 2, 3 and 4). In contrast to these results, when the same solution was excited in alkaline media at $298 \mathrm{~nm}$, the $\mathrm{Eu}^{3+}$ emission is essentially fully quenched, Fig. 4. This is quite a striking result, as unlike many antennae previously reported in the literature it is only the amide moiety in the pendant arm that can be deprotonated under these conditions ${ }^{13}$ as the antenna themselves do not possess groups capable of donating a proton. Consequently, we carried out a detailed luminescence $\mathrm{pH}$ titration of Eu1, the overall results of which are shown in Fig. 3.

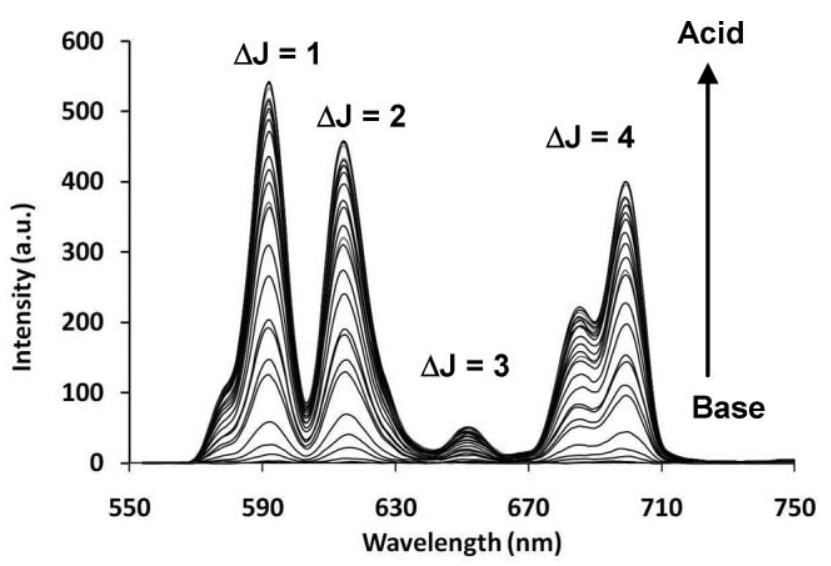

Fig. 4 Switching $\mathrm{ON}$ of the $\mathrm{Eu}^{3+}$ emission of Eu1 $\left(5 \times 10^{-6} \mathrm{~mol}^{-1} \mathrm{dm}^{-3}\right)$ as a function of $\mathrm{pH}$ (base $\rightarrow$ acid) for $\lambda_{\max } 278 \mathrm{~nm}, 25^{\circ} \mathrm{C}$ with $I=$ $0.1 \mathrm{~mol}^{-1} \mathrm{dm}^{-3}\left(\mathrm{NEt}_{4} \mathrm{ClO}_{4}\right)$ in $50: 50$ (v/v) $\mathrm{MeOH}-\mathrm{H}_{2} \mathrm{O}$.

Examination of the change in emission intensity as a function of $\mathrm{pH}$ showed that the emission intensity was unchanged until around $\mathrm{pH}$ 6.5, where upon a dramatic reduction in intensity follows as the $\mathrm{pH}$ is increased. Full quenching of the $\mathrm{Eu}^{3+}$ emission occurs above $\mathrm{pH} 10$. The $\mathrm{pH}$ range over which the $\mathrm{Eu}^{3+}$ emission intensity changes suggests that the complex, Eu1, undergoes two deprotonation steps. The $\mathrm{p} K_{\mathrm{a}}$ 's determined for the deprotonation of the Eu1 complex from the potentiometric titrations correlate very well with the $\mathrm{pH}$ range over which the $\mathrm{Eu}^{3+}$ emission intensity changes. The lifetimes of the Eu1 complex as a function of $\mathrm{pH}$ were also recorded and were only observed to change above $\mathrm{pH} 7$, as demonstrated in Fig. 3.

By plotting the changes in $\mathrm{Eu}^{3+}$ emission intensity and the lifetime of the complex with the changes in species of the Eu1 complex determined potentiometrically as a function of $\mathrm{pH}$ the species can be assigned based on the resultant photophysical changes, Fig. 3. The change in the lifetime of the complex above $\mathrm{pH} 7$ suggests that the $\mathrm{p} K_{\mathrm{a}}$ at 7.97 corresponds with the deprotonation of the metal bound water. The lifetime of the complex would be expected to be significantly altered upon deprotonation of metal bound water. Therefore, deprotonation of the nitrogen in the bonding amide can be assigned to the $\mathrm{p} K_{\mathrm{a}}$ occurring at 6.55. This $\mathrm{p} K_{\mathrm{a}}$ is significantly lower than may be expected, but can be accounted for by the inclusion of the lanthanide ion and an electron withdrawing group. This is supported by the change in the fluorescence emission as a function of $\mathrm{pH}$, Fig. 5. The largest change in fluorescence emission for Eu1 occurs between

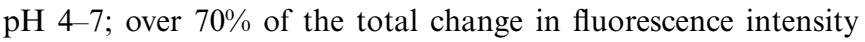
occurs over this range. The fluorescence intensity is observed to plateau above $\mathrm{pH}$ 7. Deprotonation of the amide nitrogen adjacent to the nitrophenyl group would be expected to result in the largest change in fluorescence intensity. It is also important to note that the photophysical measurements along with the potentiometric titrations were carried out in the same solvent system, $50: 50$ (v/v) $\mathrm{MeOH}-\mathrm{H}_{2} \mathrm{O}$, to allow for comparison.

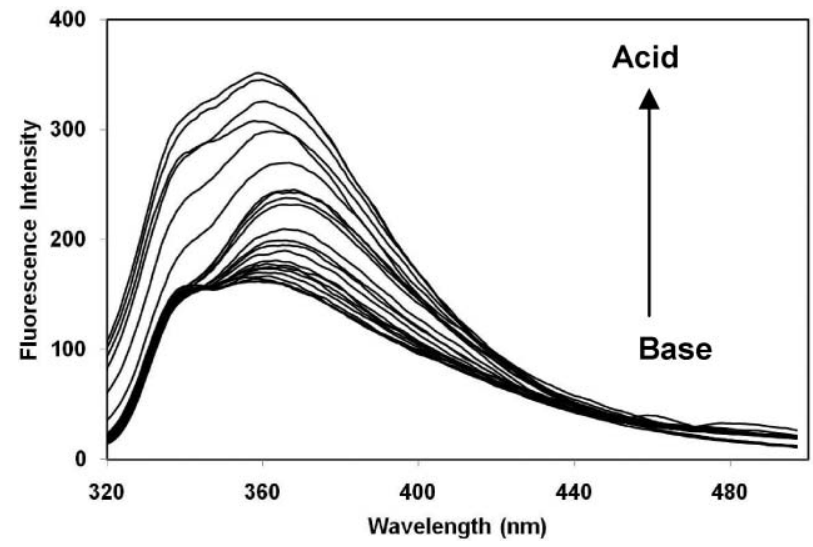

Fig. 5 Total changes in the fluorescence emission spectra with $\mathrm{pH}$ for Eu1 $\left(5 \times 10^{-6} \mathrm{~mol}^{-1} \mathrm{dm}^{-3}\right)\left(\lambda_{\max } 278 \mathrm{~nm}, 25^{\circ} \mathrm{C}\right.$ with $I=0.1 \mathrm{~mol}^{-1} \mathrm{dm}^{-3}$ $\left(\mathrm{NEt}_{4} \mathrm{ClO}_{4}\right), 50: 50$ (v/v) $\mathrm{MeOH}-\mathrm{H}_{2} \mathrm{O}$ ).

In a similar manner, excitation of $\mathbf{E u} \mathbf{2}$ at $280 \mathrm{~nm}$ gave rise to fluorescence from the naphthalene group and sensitized emission from the $\mathrm{Eu}^{3+}$ centre. The luminescence emission from the $\mathrm{Eu}^{3+}$ was sensitive to $\mathrm{pH}$. Excitation at low $\mathrm{pH}$ gave rise to strong emission from the $\mathrm{Eu}^{3+}$ centre, increasing the $\mathrm{pH}$ resulted in a significant decrease in intensity of the metal-based emission; a number of protonation steps were visible. The steps were identified by monitoring all six $J$ bands as a function of $\mathrm{pH}$. From the resultant data protonation steps occurring between 6.5-7.0 and 8.0-8.5 can be observed. These values correspond extremely well with the values reported from the potentiometric titration. Examination of the change in intensity and lifetimes of the complex as a function of $\mathrm{pH}$ plotted against the speciation diagram for Eu2, Fig. 6 allows for assignment of the protonation steps. It is worth pointing out that the profile within the neutral and acidic media is quite different from that observed for Eu2, which is most likely due to the difference in the nature of the antenna itself. This is also supported by the change in fluorescence intensity as a function of $\mathrm{pH}$ (not shown). The fluorescence emission was only observed to undergo significant modulation between the $\mathrm{pH}$ ranges of 


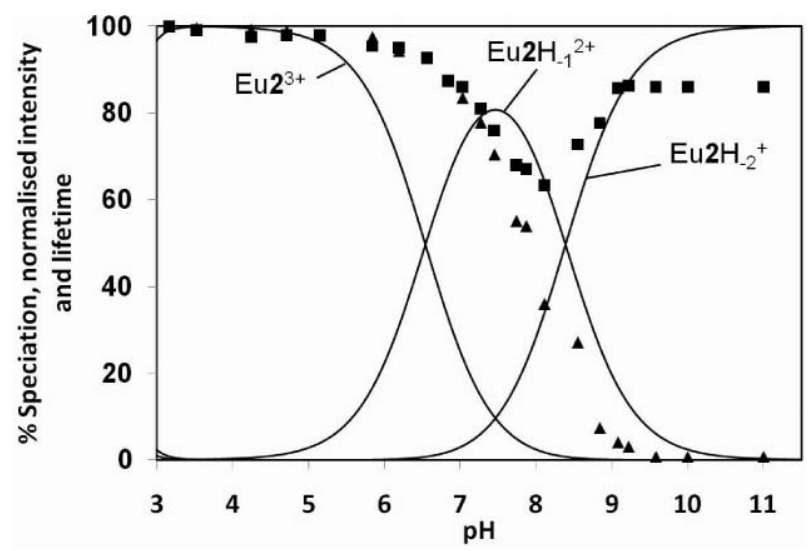

Fig. 6 Speciation variation of $\mathbf{E u 2}$ showing the species present in 50:50 $(\mathrm{v} / \mathrm{v}) \mathrm{MeOH}-\mathrm{H}_{2} \mathrm{O}$ at various $\mathrm{pH}$ in which [2] $=7.5 \times 10^{-4} \mathrm{~mol} \mathrm{dm}^{-3}$, $\left[\mathrm{H}^{+}\right]=1.1 \times 10^{-2} \mathrm{~mol} \mathrm{em}^{-3},[\mathrm{Eu}(\mathrm{III})]=1 \times 10^{-3} \mathrm{~mol} \mathrm{dm}^{-3},\left[\mathrm{NEt}_{4} \mathrm{OH}\right]=$ $0.11 \mathrm{~mol} \mathrm{dm}^{-3}, I\left(\mathrm{NEt}_{4} \mathrm{ClO}_{4}\right)=0.1 \mathrm{~mol} \mathrm{dm}^{-3}$. Speciation is shown relative to the total concentration of 1 . The normalized change in lifetime ( $\square$ ) and the $\mathrm{Eu}^{3+}$ emission intensity at $616 \mathrm{~nm}(\boldsymbol{\Delta})$ of the complex $\mathbf{E u 2}$ with $\mathrm{pH}$ is also shown.

5-7. This indicates that the deprotonation of the nitrogen amide adjacent to the naphthalene residue occurs over this $\mathrm{pH}$ range.

The combination of the four types of data (potentiometric, fluorescence, luminescence and lifetimes) has allowed for accurate assignment of the species in solution and their physical properties for both Eu1 and Eu2. This would not have been possible had the data not be examined in conjunction with each other. The accurate assignment of the species in solution, especially the deprotonation of the metal bound water $v s$. the amide is especially important for the synthesis and activity of enzyme mimics.

\section{Photophysical investigations of Eu3 and Eu4 a function of pH}

With the view of exploring the effect that introducing a spacer between the antenna and the coordinating amide has on photophysical properties Eu3 was synthesized. In addition Eu4 was also synthesized to examine if changing the pendant arms, which do not contain the antenna moiety, from a tertiary to a secondary amide has an effect on $\mathrm{Eu}(\mathrm{III})$ emission as a function of pH. Both $\mathbf{E u 3}$ and Eu4 had absorption maxima centred around $280 \mathrm{~nm}$, assigned to the $\pi-\pi^{*}$ transition of the naphthalene group. This is similar to Eu2 as expected. Slight hyperchromic shifts were observed for the band centered at $280 \mathrm{~nm}$ for both complexes at elevated $\mathrm{pH}$; the largest changes been seen between $\mathrm{pH}$ 10-13. The effect was reversible in each case.

Similar $\mathrm{pH}$ dependent changes were seen in fluorescence emission spectrum over the same $\mathrm{pH}$ range, where the emission was ca. $50 \%$ quenched in alkaline pH. For both $\mathbf{E u 3}$ and Eu4, upon excitation at $278 \mathrm{~nm}$, the formation of an emission band centered at $\sim 340 \mathrm{~nm}$ was observed, which was similar to that seen for Eu2 above.

Excitation of the antenna at $278 \mathrm{~nm}$ in Eu3 and Eu4 also gave rise to $\mathrm{Eu}(\mathrm{III})$ centred emission. At neutral $\mathrm{pH}$, the hydration states were found to be 1.1 and 1.5 for $\mathbf{E u 3}$ and Eu4, respectively. The intensity of the $\mathrm{Eu}(\mathrm{III})$ emission when excited at $281 \mathrm{~nm}$ was also recorded as a function of $\mathrm{pH}$. The Eu(III) emission for both $\mathbf{E u 3}$ and Eu4 was enhanced by $c a$. 10 fold at high pH (above pH 10), This indicates that both $\mathbf{E u} 3$ and $\mathbf{E u} 4$ have a $\mathrm{p} K_{\mathrm{a}}$ in the range of 11.5-12, e.g. Fig. 7, for Eu3. On comparison of the $\mathrm{pH}$ range over which both the $\mathrm{Eu}^{3+}$ emission intensity and the fluorescence intensity changes for $\mathbf{E u} \mathbf{2}$ and $\mathbf{E u} \mathbf{3}$ we can see that the acidity of the system decreased as the distance between the amide and the aromatic group increased. This supports the argument that the presence of an electron withdrawing group adjacent to the amide significantly alters the acidity of this group, with concomitant changes in the $\mathrm{pH}$ response of the $\mathrm{Eu}(\mathrm{III})$ emission.

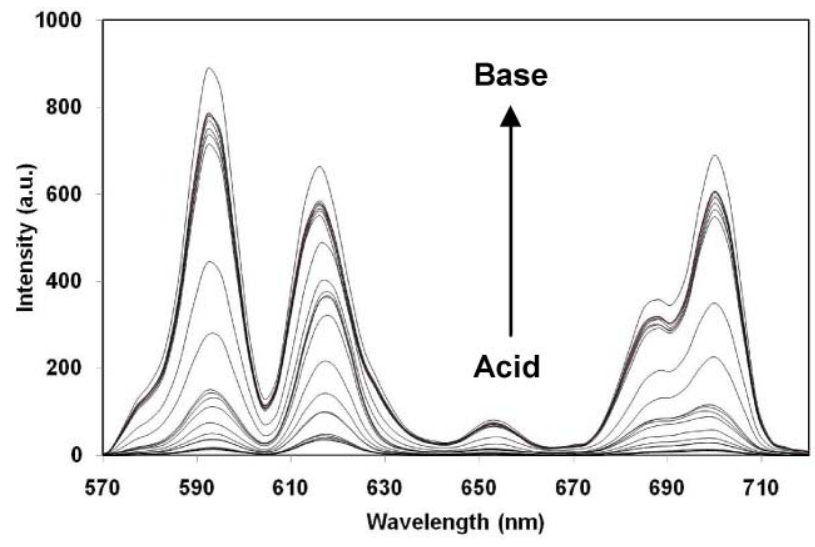

Fig. 7 Variation of the $\mathrm{Eu}^{3+}$ emission intensity with $\mathrm{pH}$ for $\mathbf{E u 3}(2.0 \times$ $\left.10^{-5} \mathrm{~mol}^{-1} \mathrm{dm}^{-3}\right)\left(\lambda_{\max } 278 \mathrm{~nm}, 25^{\circ} \mathrm{C}\right.$ with $I=0.1 \mathrm{~mol}^{-1} \mathrm{dm}^{-3}\left(\mathrm{NEt}_{4} \mathrm{ClO}_{4}\right)$, $\left.50: 50(\mathrm{v} / \mathrm{v}) \mathrm{MeOH}-\mathrm{H}_{2} \mathrm{O}\right)$.

\section{Photophysical investigations of Eu5-7 as a function of $\mathrm{pH}$}

With the view of attempting to quantify the effect of $\mathrm{pH}$ on the $\mathrm{Eu}(\mathrm{III})$ emission further, we next investigated a series of complexes that lack any antennae. It was anticipated that the results from these investigation would help quantify the effect of $\mathrm{pH}$ on lanthanide bound water molecules as well as give some insight into the effect $\mathrm{pH}$ has on structural changes within such simple cyclen based systems; where only the amide moieties are modified, being $\mathrm{NH}_{2}$, NHMe and $\mathrm{NMe}_{2}$ for $\mathbf{5 , 6}$ and $\mathbf{7}$, respectively.

In the case of Eu5-Eu7, which are well known structures, the lack of antennae means excitation of the $\mathrm{Eu}(\mathrm{III})$ ion can only be achieved through direct excitation at the metal centre at $395 \mathrm{~nm}$. The changes in the $\mathrm{Eu}(\mathrm{III})$ emission as a function of $\mathrm{pH}$ were monitored in a similar manner to that seen for Eu1 and Eu2. The overall changes in the $\mathrm{Eu}(\mathrm{III})$ emission of $\mathbf{E u 5}$ as a function of $\mathrm{pH}$ is shown in Fig. 8A, which demonstrates significant emission changes as a function of $\mathrm{pH}$. By plotting the intensity changes against $\mathrm{pH}$ as shown in Fig. 8B, it can be seen that within acidic and neutral $\mathrm{pH}$ regions, the emission can be considered as being $\mathrm{pH}$ independent. While at more alkaline $\mathrm{pH}$ the emission from the hypersensitive $\Delta J=2$ transition is initially "enhanced" up to $c a$. $\mathrm{pH}$ 11, but thereafter, the emission is quenched. In contrast, the emission arising from the $\Delta J=1$ and 4 transitions, is quenched within the same alkaline region.

With the view of further analyzing this $\mathrm{pH}$ dependence, the excited state lifetimes of the $\mathrm{Eu}(\mathrm{III})$ emission were recorded as a function of $\mathrm{pH}$, which showed that in acidic and neutral $\mathrm{pH}$ regions $(c a . \mathrm{pH} 2 \rightarrow 8$ ) the lifetimes in water remained constant. However, above $\mathrm{pH} 8$ a slight shift occurred and above $\mathrm{pH} 11$ the lifetimes became significantly longer. Plotting the changes as 

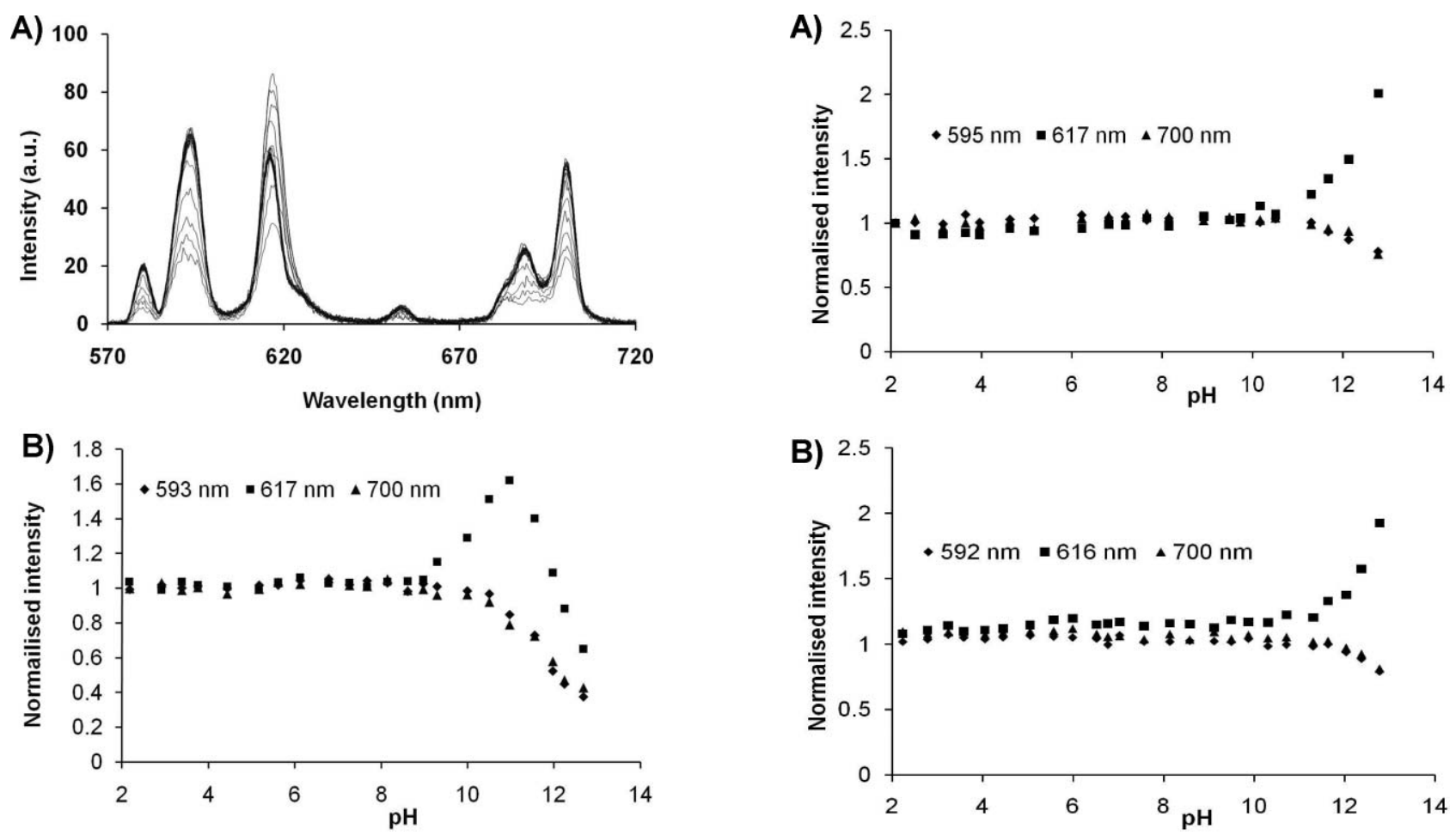

Fig. 8 A) The overall changes in the Eu(III) emission of Eu5 $(5 \times$ $10^{-4} \mathrm{~mol} \mathrm{dm}^{-3}$ ) upon excitation into the $\mathrm{Eu}(\mathrm{III})$ ion directly in $\mathrm{NEt}_{4} \mathrm{OH}$ at $298.2( \pm 0.2) \mathrm{K}, I=0.01 \mathrm{M}\left(\mathrm{NEt}_{4} \mathrm{ClO}_{4}\right)$ in $100 \% \mathrm{H}_{2} \mathrm{O}$ solution. B) The normalized emission changes observed at 593, 617 and $700 \mathrm{~nm}$, respectively, for the $\mathrm{Eu}(\mathrm{III})$ emission as a function of $\mathrm{pH}$.

a function of $\mathrm{pH}$, gave a profile that resembled that seen for the changes in the $\Delta J=2$ transition.

We next repeated the pH titrations using Eu6 and Eu7. Similar changes were seen in the Eu(III) emission spectra of these

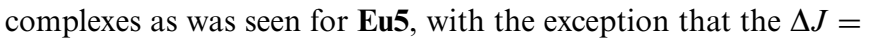
2 transition was not quenched at high $\mathrm{pH}$.

The analysis of the three transitions $\Delta J=1,2$ and 4 is shown in Fig. 9A and Fig. 9B, for Eu6 and Eu7, respectively. This demonstrates again, that the emission from the hypersensitive $\Delta J=2$ transition is enhanced in alkaline $\mathrm{pH}$, while the $\Delta J=$ 1 and 4 transitions are quenched. While we were unable to fit this data to give accurate protonation constants, it is clear from these profiles that the nature of the amide substituent has a significant affect on the emission. The change in Eu(III) emission can only be assigned to either, the deprotonation of metal bound water molecules, or the deprotonation of the amides. The former, would be expected to have $\mathrm{p} K_{\mathrm{a}}$ around $\mathrm{p} K_{\mathrm{a}} \sim 8-9$. Hence, as the emission is most significantly affected for the primary amide $\mathbf{5}$, we propose that the observed modulation in the $\mathrm{Eu}(\mathrm{III})$ emission is more to do with deprotonation of the amide moieties, or that in highly basic media, the complexes undergo some structural changes that effects $\Delta J=2$, which is highly sensitive to the coordination environment of the complexes.

Unfortunately, we were, as discussed above, unable to determine the $\mathrm{p} K_{\mathrm{a}}$ 's of these complexes using potentiometric measurements due to early precipitation for these systems. The $\mathrm{pH}$ at which precipitation of these complexes occurred supports the formation of the metal bound hydroxyl species. However, at the low

Fig. 9 A) The normalized Eu(III) emission changes for Eu6 observed at 592, 617 and $700 \mathrm{~nm}$ as a function of pH. B) The same observed for Eu7.

concentrations required for spectroscopy, this process in these systems does not give rise to significant changes in the $\mathrm{Eu}(\mathrm{III})$ emission, clearly demonstrating that the interruption of any such changes in the metal centred emission can be difficult to elucidate.

\section{Conclusions}

In conclusion, we have shown how a range of physical measurements can be exploited in the effort to understand the formation of species in solution. By comparing changes in physical properties through a range of techniques the assignment of complex protonation steps was made feasible. We have also demonstrated that the emission arising from the lanthanide ion can be highly sensitive to the nature of the pendant arms, as the Lewis acid nature of lanthanide and the nature of the amide substituent's can enable various competitive deprotonation processes to be activated which result in the modulation of the lanthanide emission.

\section{Experimental}

\section{2-Chloro- $N$-naphthalen-1-yl-acetamide 8}

1-Amino naphthalene ( $1 \mathrm{~g}, 6.9 \mathrm{mmol})$ was dissolved in a solution of DCM $\left(40 \mathrm{~cm}^{3}\right)$ and triethylamine $\left(1.78 \mathrm{~cm}^{3}, 13 \mathrm{mmol}\right)$, the mixture was cooled to $0{ }^{\circ} \mathrm{C}$. A solution of chloroacetyl chloride $\left(0.828 \mathrm{~cm}^{3}, 10.4 \mathrm{mmol}\right)$ in DCM $\left(30 \mathrm{~cm}^{3}\right)$ was then added dropwise to the reaction mixture at $0{ }^{\circ} \mathrm{C}$. The reaction was left to warm to room temperature overnight and then quenched with a dropwise addition of water $\left(15 \mathrm{~cm}^{3}\right)$. The organic layer was then washed with $0.1 \mathrm{~mol} \mathrm{dm}^{-3}$ hydrochloric acid and a saturated solution of sodium hydrogen carbonate. The organic layer was then dried and the solvent removed under reduced pressure to give a brown 
solid. Purification by means of a silica squat column $[100 \%$ DCM, $\left.R_{\mathrm{f}} 0.8\right]$ yielded an off white solid $(1.11 \mathrm{~g}, 74 \%), \delta_{\mathrm{H}}(400 \mathrm{MHz}$; $\left.\mathrm{CDCl}_{3}\right) 4.38\left(2 \mathrm{H}, \mathrm{s}, \mathrm{CH}_{2} \mathrm{Cl}\right), 7.51-7.60(3 \mathrm{H}, \mathrm{m}, \mathrm{Ar}-\mathrm{H}), 7.77(1 \mathrm{H}$, d, Ar-H), $7.91(2 \mathrm{H}, \mathrm{t}, \mathrm{Ar}-\mathrm{H}), 8.00(1 \mathrm{H}, \mathrm{d}, \mathrm{Ar}-\mathrm{H}) ; \delta_{\mathrm{C}}(100 \mathrm{MHz}$; $\left.\mathrm{CDCl}_{3}\right) 42.9\left(\mathrm{CH}_{2} \mathrm{Cl}\right), 119.7,120.1,125.5,125.8,126.0,126.2$, 126.4, 128.4, 130.6, 133.6 (Ar-H), $163.9(\mathrm{C}=\mathrm{O}) ; \mathrm{m} / z$ (ESMS) $\left(\mathrm{M}-\mathrm{Na}^{+}\right)$Found: 242.0341. $\mathrm{C}_{12} \mathrm{H}_{10} \mathrm{NONaCl}$ requires 242.0349, $\mathrm{C}_{12} \mathrm{H}_{10} \mathrm{NClO}$ : C, 65.61; H, 4.59; N, 6.38; Found: C, 65.35; H 4.51; N, 6.08; Calculated for $\mathrm{C}_{12} \mathrm{H}_{10} \mathrm{NClO}$, IR $v_{\max } / \mathrm{cm}^{-1} 3255,3051$, 3028, 2922, 2852, 1665, 1557, 1397, 1348, 1268, 1248, 1207, 967, $960,813,790,769,742,718$.

\section{2-Chloro- $N$-naphthalen-1-yl-methyl-acetamide 9}

The naphthalene methylamine $\left(0.46 \mathrm{~cm}^{3}, 3.18 \mathrm{mmol}\right)$ was added to a stirred solution of chloroacetic anhydride $(547 \mathrm{mg}, 3.19 \mathrm{mmol})$, and triethylamine $\left(0.1 \mathrm{~cm}^{3}, 0.73 \mathrm{mmol}\right)$ in DCM $\left(25 \mathrm{~cm}^{3}\right)$. The solution was left stirring overnight at room temperature. The solution was washed with acid $\left(1 \mathrm{~mol} \mathrm{dm}^{-3} \mathrm{HCl}, 30 \mathrm{~cm}^{3}\right)$ and distilled water $\left(30 \mathrm{~cm}^{3}\right)$ and then dried over magnesium sulfate. The solution was filtered and the solvent removed under reduced pressure. The resulting solid was dried under vacuum for several hours to yield a white solid $(0.417 \mathrm{~g}, 56 \%)$. Calculated for $\mathrm{C}_{13} \mathrm{H}_{12} \mathrm{NClO}$ : C, 66.81; H 5.18; N, 5.99, Found: C, 66.63; H, 4.96; N, 5.99; Calculated for $\mathrm{C}_{13} \mathrm{H}_{12} \mathrm{NClO}$ : [M + Na peak $] m / z=256.69$, Found, 256.05: $\delta_{\mathrm{H}}\left(400 \mathrm{MHz}, \mathrm{CDCl}_{3}\right) 7.98(1 \mathrm{H}, \mathrm{d}, J=7.52 \mathrm{~Hz}$, $\mathrm{Ar}-\mathrm{CH}), 7.91(1 \mathrm{H}, \mathrm{d}, J=7.52, \mathrm{Ar}-\mathrm{CH}), 7.85(1 \mathrm{H}, \mathrm{m}, \mathrm{Ar}-\mathrm{CH}), 7.56$ $(2 \mathrm{H}, \mathrm{m}, \mathrm{Ar}-\mathrm{CH}), 7.52(2 \mathrm{H}, \mathrm{m}, \mathrm{Ar}-\mathrm{CH}), 6.85(1 \mathrm{H}, \mathrm{s}, \mathrm{N}-\mathrm{H}), 4.95$ $\left(2 \mathrm{H}, \mathrm{d}, J=5.52 \mathrm{~Hz}, \mathrm{CH}_{2}\right), 4.11\left(2 \mathrm{H}, \mathrm{s}, \mathrm{CH}_{2}\right) ; \delta_{\mathrm{C}}\left(100 \mathrm{MHz}, \mathrm{CDCl}_{3}\right)$ $165.56(\mathrm{C}=\mathrm{O}), 133.82(\mathrm{qC}), 132.47(\mathrm{qC}), 131.25(\mathrm{qC}), 128.9(\mathrm{Ar}-$ $\mathrm{CH}), 128.84(\mathrm{Ar}-\mathrm{CH}), 126.78$ (Ar-CH), 126.69 (Ar-CH), 126.08 (Ar-CH), 125.34 (Ar-CH), $123.13(\mathrm{Ar}-\mathrm{CH}), 42.53\left(\mathrm{CH}_{2)} 41.93\right.$ $\left(\mathrm{CH}_{2}\right)$; Mass Spec (MeCN, ES+) $m / z$ Expected: 233.7, found 234.1 $(\mathrm{M}+\mathrm{H}), 256.0(\mathrm{M}+\mathrm{Na}) ; \mathrm{IR} v_{\max } / \mathrm{cm}^{-1} 3281,3059,3043,3010$, 2956, 2887, 1644, 1546, 1511, 1471, 1422, 1397, 1226, 799, 784, $730,703,675,563,554,449$.

\section{1,4,7-Tris(dimethylcarbamoylmethyl)-1,4,7,10- tetraazacyclododecane 10}

Cyclen $(1 \mathrm{~g}, 5.8 \mathrm{mmol})$ and sodium hydrogen carbonate $(1.42 \mathrm{~g}$, $17.4 \mathrm{mmol}$ ) were dissolved in $\mathrm{CH}_{3} \mathrm{CN}$ and the solution cooled to $0{ }^{\circ} \mathrm{C}$, a solution of the $\alpha$-chloroamide of dimethylamine $(2.11 \mathrm{~g}$, $17.4 \mathrm{mmol}$ ) in $\mathrm{CH}_{3} \mathrm{CN}$ was then added quickly. The reaction was then heated at reflux for 4 days. The reaction was then filtered through Celite and the solvent removed under reduced pressure. The residue was then re-dissolved in DCM $\left(20 \mathrm{~cm}^{3}\right)$ and the solution filtered. Purification by column chromatography [gradient elution 100\% DCM-MeOH $80: 20(\mathrm{v} / \mathrm{v}), R_{\mathrm{f}} 0.3$ ] yielded ligand 10 as an off white solid $(1.5 \mathrm{~g}, 60 \%) ; \delta_{\mathrm{H}}\left(400 \mathrm{MHz} ; \mathrm{CDCl}_{3}\right)$ $2.84\left(8 \mathrm{H}, \mathrm{s}\right.$, cyclen $\left.\mathrm{CH}_{2}\right), 2.89\left(9 \mathrm{H}, \mathrm{s}, \mathrm{CH}_{3}\right), 2.97\left(6 \mathrm{H}, \mathrm{s}, \mathrm{CH}_{3}\right), 3.04$ $\left(3 \mathrm{H}, \mathrm{s}, \mathrm{CH}_{3}\right), 3.09\left(8 \mathrm{H}\right.$, s, cyclen $\left.\mathrm{CH}_{2}\right), 3.58\left(4 \mathrm{H}, \mathrm{s}, \mathrm{CH}_{2} \mathrm{~N}\right), 3.59$ $\left(2 \mathrm{H}, \mathrm{s}, \mathrm{CH}_{2} \mathrm{~N}\right) ; \delta_{\mathrm{C}}\left(100 \mathrm{MHz} ; \mathrm{CDCl}_{3}\right) 34.9,36.0,36.4,45.7,49.3$, 50.5, 51.2, 53.3, 55.2 $\left(\mathrm{CH}_{2} \mathrm{~N}\right.$ and $\left.\mathrm{CH}_{3} \mathrm{~N}\right), 169.9,169.8(\mathrm{C}=\mathrm{O}) ; \mathrm{m} / \mathrm{z}$ (ESMS) $450.4\left(\mathrm{M}-\mathrm{Na}^{+}\right)$.

2-(4,7-Bis-methylcarbamoylmethyl-1,4,7,10-tetraaza-cyclododec1-yl)- $N$-methyl-acetamide 11

Cyclen $(0.2645 \mathrm{~g}, 1.535 \mathrm{mmol})$, sodium hydrogen carbonate $(0.379 \mathrm{~g}, 4.52 \mathrm{mmol})$ and 2-chloro- $N$-methyl acetamide $(0.5 \mathrm{~g}$,
$4.67 \mathrm{mmol})$ were dissolved in $\mathrm{CH}_{3} \mathrm{CN}\left(20 \mathrm{~cm}^{3}\right)$ and heated at reflux for $72 \mathrm{~h}$. After removal of the solvent under reduced pressure the resultant yellow oil was redissolved in the minimum amount of ethanol and added dropwise to a stirred solution of diethyl ether. The solution was left to stir for 30 min during which a white precipitate became visible. The ether was removed and the solid dried under high vacuum to yield ligand $\mathbf{1 1}$ as an white solid $(0.31 \mathrm{~g}, 52 \%)$. Calculated for $\mathrm{C}_{17} \mathrm{H}_{35} \mathrm{~N}_{7} \mathrm{O}_{3}:[\mathrm{M}+\mathrm{H}$ peak $] \mathrm{m} / \mathrm{z}=$ 386.5, Found $=386.28: \delta_{\mathrm{H}}\left(400 \mathrm{MHz}, \mathrm{CDCl}_{3}\right) 8.12(1 \mathrm{H}, \mathrm{N}-\mathrm{H})$, $8.01(1 \mathrm{H}, \mathrm{N}-\mathrm{H}), 7.95(1 \mathrm{H}, \mathrm{N}-\mathrm{H}), 3.31\left(4 \mathrm{H}, \mathrm{s}, \mathrm{CH}_{2}\right), 3.25(2 \mathrm{H}, \mathrm{s}$, $\left.\mathrm{CH}_{2}\right), 2.97\left(8 \mathrm{H}, \mathrm{m}, \mathrm{CH}_{2}\right), 2.81\left(5 \mathrm{H}, \mathrm{d}, J=4.52, \mathrm{CH}_{2}\right), 2.77(6 \mathrm{H}, \mathrm{d}$, $\left.J=4.52, \mathrm{CH}_{2}\right), 2.66\left(3 \mathrm{H}, \mathrm{m}, \mathrm{CH}_{3}\right) ; \delta_{\mathrm{C}}\left(100 \mathrm{MHz}, \mathrm{CDCl}_{3}\right) 172.31$ $\left.(\mathrm{C}=\mathrm{O}), 171.83(\mathrm{C}=\mathrm{O}), 60.97\left(\mathrm{CH}_{2}\right), 56.09 \mathrm{CH}_{2}\right), 55.93\left(\mathrm{CH}_{2}\right)$, $53.77\left(\mathrm{CH}_{2}\right), 52.33\left(\mathrm{CH}_{2}\right), 47.17\left(\mathrm{CH}_{2}\right), 26.03\left(\mathrm{CH}_{3}\right)$; Mass Spec (MeCN, ES+) $m / z$ Expected: 385.5, Found: $386.2(\mathrm{M}+\mathrm{H}$ ), 408.2 $(\mathrm{M}+\mathrm{Na}) ; \mathrm{IR} v_{\max } / \mathrm{cm}^{-1} 3534,3266,2943,2830,1667,1651,1634$, 1563, 1557, 1456, 1411, 1310, 1244, 1163, 1109, 730.

\section{1-(4-Aminonapthylcarbamoyl) tris(dimethyl-carbamoylmethyl)-1, 4,7,10-tetraazacyclododecane 2}

Compound 10 (400 mg, $0.93 \mathrm{mmol}$ ), compound 8 (204 mg, $0.93 \mathrm{mmol})$ and diissopropylethylamine $\left(0.486 \mathrm{~cm}^{3}, 2.8 \mathrm{mmol}\right)$ were dissolved in DMF and the reaction left to stir at room temperature for 7 days. The solvent was removed under reduced pressure and the residue was then redissolved in DCM and washed with water to yield a white solid $(513 \mathrm{mg}, 90 \%) ; \delta_{\mathrm{H}}(400 \mathrm{MHz}$; $\left.\mathrm{CDCl}_{3}\right) 2.56\left(16 \mathrm{H}, \mathrm{m}\right.$, cyclen $\left.\mathrm{CH}_{2}\right), 2.83\left(6 \mathrm{H}, \mathrm{s}, \mathrm{CH}_{3}\right), 2.90(6 \mathrm{H}, \mathrm{s}$, $\left.\mathrm{CH}_{3}\right), 2.95\left(6 \mathrm{H}, \mathrm{s}, \mathrm{CH}_{3}\right), 3.39\left(2 \mathrm{H}, \mathrm{s}, \mathrm{CH}_{2} \mathrm{~N}\right), 3.44\left(6 \mathrm{H}, \mathrm{s}, \mathrm{CH}_{2} \mathrm{~N}\right)$, 7.35-7.48 (4H, m, Ar-H), 7.76-7.87 (3H, d, Ar-H); $\delta_{\mathrm{C}}(100 \mathrm{MHz}$; $\left.\mathrm{CDCl}_{3}\right) 35.0,35.67,53.04,54.26,54.47,54.53,56.94\left(\mathrm{CH}_{2} \mathrm{~N}\right.$ and $\left.\mathrm{CH}_{3} \mathrm{~N}\right), 121.39,123.74,124.64,124.74,124.86,125.12,125.17$, 125.37, 127.16, 128.09 (Ar-H), 170.26, 170.44, 170.55, (C=O); $m / z$ (ESMS) $633\left(\mathrm{M}-\mathrm{Na}^{+}\right)$; HRMS: $m / z$ (ESMS) Found: 633.3866 $\mathrm{C}_{32} \mathrm{H}_{50} \mathrm{~N}_{8} \mathrm{O}_{4} \mathrm{Na}$ requires 633.3853 .

\section{$\mathrm{N}$-Naphthalen-1-ylmethyl-2-(4,7,10- tris-dimethyl-carbamoyl methyl-1,4,7,10 tetraaza cyclododec-1-yl)- acetamide 3}

Compound 10. (197.6 mg, $0.461 \mathrm{mmol}$ ), compound 8 (110.4 mg, $0.472 \mathrm{mmol}$ ) and caesium carbonate $(155.9 \mathrm{mg}, 0.478 \mathrm{mmol}$ ) were dissolved in dry $\mathrm{CH}_{3} \mathrm{CN}\left(15 \mathrm{~cm}^{3}\right)$ and heated at reflux under argon for $48 \mathrm{~h}$. After refluxing the solution was left to cool to room temperature and was then filtered using Celite. The solvent was removed under reduced pressure and the resulting solid was dissolved in the minimum amount of DCM. This resin was then passed down an alumina column using DCM with increasing amounts of ethanol as a solvent to yield ligand $\mathbf{3}$ as a light yellow solid $(0.195 \mathrm{~g}, 67.5 \%)$. Calculated for $\mathrm{C}_{33} \mathrm{H}_{52} \mathrm{~N}_{8} \mathrm{O}_{4}$ : [M + H peak] $m / z=624.83$, Found $=625.42: \delta_{\mathrm{H}}\left(400 \mathrm{MHz}, \mathrm{CDCl}_{3}\right) 7.99(1 \mathrm{H}, \mathrm{d}$, $J=8.04 \mathrm{~Hz}$ Ar-CH), $7.75(1 \mathrm{H}, \mathrm{d}, J=7.53 \mathrm{~Hz}, \mathrm{Ar}-\mathrm{CH}), 7.60(1 \mathrm{H}$, d, $J=8.04 \mathrm{~Hz}, \mathrm{Ar}-\mathrm{CH}), 7.52(1 \mathrm{H}, \mathrm{d}, J=6.53 \mathrm{~Hz}, \mathrm{Ar}-\mathrm{CH}), 7.39$ $(2 \mathrm{H}, \mathrm{m}, \mathrm{Ar}-\mathrm{CH}), 7.27(1 \mathrm{H}, \mathrm{m}, \mathrm{Ar}-\mathrm{CH}), 4.75(1 \mathrm{H}, \mathrm{s}, \mathrm{N}-\mathrm{H}), 3.33$ $\left(2 \mathrm{H}, \mathrm{m}, \mathrm{CH}_{2}\right), 3.11\left(2 \mathrm{H}, \mathrm{m}, \mathrm{CH}_{2}\right), 2.97\left(5 \mathrm{H}, \mathrm{m}, \mathrm{CH}_{2}\right), 2.93(10 \mathrm{H}, \mathrm{m}$, $\left.\mathrm{CH}_{2}\right), 2.81\left(1 \mathrm{H}, \mathrm{m}, \mathrm{CH}_{2}\right), 2.79\left(15 \mathrm{H}, \mathrm{m}, \mathrm{CH}_{2} / \mathrm{CH}_{3}\right), 2.31(5 \mathrm{H}, \mathrm{m}$, $\left.\mathrm{CH}_{3}\right) ; \delta_{\mathrm{C}}\left(100 \mathrm{MHz}, \mathrm{CDCl}_{3)} 171.4(\mathrm{C}=\mathrm{O}), 170.51(\mathrm{C}=\mathrm{O}), 170.34\right.$ $(\mathrm{C}=\mathrm{O}), 134.73(\mathrm{qC}), 133.23(\mathrm{qC}), 130.96(\mathrm{qC}), 128.12(\mathrm{Ar}-\mathrm{CH})$, 126.92 (AR-CH), 125.7 (Ar-CH), 125.25 (Ar-CH), 124.54 (AR$\mathrm{CH}), 123.23(\mathrm{Ar}-\mathrm{CH}), 57.03\left(\mathrm{CH}_{2}\right), 54.67\left(\mathrm{CH}_{2}\right), 54.46\left(\mathrm{CH}_{2}\right)$, $53.33\left(\mathrm{CH}_{2}\right), 51.04\left(\mathrm{CH}_{2}\right), 50.38\left(\mathrm{CH}_{2}\right), 40.11\left(\mathrm{CH}_{2}\right), 35.52\left(\mathrm{CH}_{3}\right)$, 
35.17 $\left(\mathrm{CH}_{3}\right), 35.14\left(\mathrm{CH}_{3}\right)$; Mass Spec (MeCN, ES+) $m / z$ Expected: 624.79, Found: $625.41[\mathrm{M}+\mathrm{H}], 647.39[\mathrm{M}+\mathrm{Na}]$.

\section{$\mathrm{N}$-Naphthalen-1-ylmethyl-2-(4,7,10-tris-methylcarbamoyl-methyl- 1,4,7,10tetraaza-cyclododec-1-yl)-acetamide 4}

Compound 11 (0.0987 g, $2.56 \mathrm{mmol})$, compound 9 (0.0541 g, $2.314 \mathrm{mmol})$ and caesium carbonate $(0.097 \mathrm{~g}, 0.298 \mathrm{mmol})$ were dissolved in dry $\mathrm{CH}_{3} \mathrm{CN}\left(15 \mathrm{~cm}^{3}\right)$ and heated at reflux under argon for $48 \mathrm{~h}$. After refluxing the solution was left to cool to room temperature and was then filtered using Celite. The solvent was removed under reduced pressure and the resulting solid was dissolved in the minimum amount of DCM. This resin was then passed down an alumina column using DCM and increasing amounts of ethanol as a solvent to yield ligand $\mathbf{4}$ as a light yellow solid $(0.1014 \mathrm{~g}, 75.2 \%)$. Calculated for $\mathrm{C}_{30} \mathrm{H}_{46} \mathrm{~N}_{8} \mathrm{O}_{4}$ : [M + H peak] $m / z=583.75$, Found $=583.37: \delta_{\mathrm{H}}(400 \mathrm{MHz}, \mathrm{MeOH}) 8.12(1 \mathrm{H}$, $\mathrm{d}, J=8.0 \mathrm{~Hz}, \mathrm{Ar}-\mathrm{CH}), 7.92(1 \mathrm{H}, \mathrm{m}, \mathrm{Ar}-\mathrm{CH}), 7.83(1 \mathrm{H}, \mathrm{d}, J=$ $8.04 \mathrm{~Hz}, \mathrm{Ar}-\mathrm{CH}), 7.54(3 \mathrm{H}, \mathrm{m}, \mathrm{Ar}-\mathrm{CH}), 7.45(1 \mathrm{H}, \mathrm{m}, \mathrm{Ar}-\mathrm{CH})$, $3.32\left(6 \mathrm{H}, \mathrm{m}, \mathrm{CH}_{2}\right), 3.08\left(8 \mathrm{H}, \mathrm{m}, \mathrm{CH}_{2}\right), 2.76\left(20 \mathrm{H}, \mathrm{m}, \mathrm{CH}_{2} / \mathrm{CH}_{3}\right)$, $2.36\left(5 \mathrm{H}, \mathrm{m}, \mathrm{CH}_{3}\right) ; \delta_{\mathrm{C}}\left(100 \mathrm{MHz}, \mathrm{CDCl}_{3}\right) 173.21(\mathrm{C}=\mathrm{O}), 172.80$ $(\mathrm{C}=\mathrm{O}), 172.18(\mathrm{C}=\mathrm{O}), 134.37(\mathrm{qC}), 134.25(\mathrm{qC}), 134.18(\mathrm{qC})$, 128.89 (Ar-CH), 128.73 (Ar-CH), 126.35 (Ar-CH), 125.95 (Ar$\mathrm{CH}), 125.83(\mathrm{Ar}-\mathrm{CH}), 125.54(\mathrm{Ar}-\mathrm{CH}), 125.44(\mathrm{Ar}-\mathrm{CH}), 123.32$ (Ar-CH), $63.59\left(\mathrm{CH}_{2}\right), 61.65\left(\mathrm{CH}_{2}\right), 58.51\left(\mathrm{CH}_{2}\right), 57.11\left(\mathrm{CH}_{2}\right)$, $52.86\left(\mathrm{CH}_{2}\right), 51.13\left(\mathrm{CH}_{2}\right), 50.43\left(\mathrm{CH}_{2}\right), 25.35\left(\mathrm{CH}_{3}\right), 25.32\left(\mathrm{CH}_{3}\right)$; Mass Spec (MeCN, ES+) $m / z$ Expected: 582.75, Found: 583.91 $[\mathrm{M}+\mathrm{H}], 605.92[\mathrm{M}+\mathrm{Na}]) ; \mathrm{IR} v_{\max } / \mathrm{cm}^{-1} 3419,3266,3073,2945$, 2824, 1664, 1554, 1451, 1411, 1355, 1310, 1240, 1160, 1107, 992, $971,915,890,805,780,729,600$.

\section{Eu(III) complex of ligand 1, Eu1}

$\mathrm{Eu}\left(\mathrm{ClO}_{4}\right)_{3}\left(0.031 \mathrm{~cm}^{3}, 0.051 \mathrm{mmol}\right)$ was added to a stirred solution of ligand $\mathbf{1}(31 \mathrm{mg}, 0.051 \mathrm{mmol})$ in $\mathrm{MeOH}\left(2 \mathrm{~cm}^{3}\right)$ a precipitate formed, which was redissolved in $\mathrm{CH}_{3} \mathrm{CN}\left(5 \mathrm{~cm}^{3}\right)$. The solvent was then left to evaporate and the resultant solid dried under reduced pressure to yield a yellow solid $(27 \mathrm{mg}, 70 \%) ; \delta_{\mathrm{H}}(400 \mathrm{MHz}$; $\left.\mathrm{CDCl}_{3}\right)-8.47,-6.51,-0.99,0.29,1.13,1.28,1.33,1.72,1.97,2.13$, 2.92, 3.18, 3.43, 4.04, 8.26, 9.49, 10.13, $\mathrm{m} / \mathrm{z}$ (ESMS) $378\left(\mathrm{M}^{+} / 2\right)$; HRMS: $m / z$ (ESMS) Found: $758.19 \mathrm{C}_{28} \mathrm{H}_{47} \mathrm{~N}_{9} \mathrm{O}_{6} \mathrm{Eu}$ requires 757.69. Found C 31.67, H 4.77, N 10.11. Expected C 31.85, H $4.49, \mathrm{~N} 11.94 \mathrm{C}_{28} \mathrm{H}_{47} \mathrm{~N}_{9} \mathrm{O}_{6} \mathrm{Eu}^{+} .\left(\mathrm{ClO}_{4}^{-}\right)_{3}$.

\section{Eu(III) complex of ligand 2, Eu2}

$\mathrm{Eu}\left(\mathrm{ClO}_{4}\right)_{3}\left(0.080 \mathrm{~cm}^{3}, 0.132 \mathrm{mmol}\right)$ was added to a stirred solution of ligand $2(81 \mathrm{mg}, 0.132 \mathrm{mmol})$ in $\mathrm{MeOH}\left(2 \mathrm{~cm}^{3}\right)$. A precipitate formed, which was redissolved in $\mathrm{CH}_{3} \mathrm{CN}\left(5 \mathrm{~cm}^{3}\right)$. The solvent was then left to evaporate and the resultant solid dried under reduced pressure to yield a yellow solid. The solid was resuspended in $\mathrm{CH}_{3} \mathrm{CN}$ and $\mathrm{CH}_{2} \mathrm{Cl}_{2}$, ether was then added and the resulting solid collected and dried under vacuum to yield Eu2 (81.9 mg 81.5\%); $\delta_{\mathrm{H}}\left(400 \mathrm{MHz} ; \mathrm{CDCl}_{3}\right)-7.92,-5.41,-0.36$, $0.90,1.29,1.96,2.83,3.57,3.85,4.10,7.59,8.00,8.12,8.59,15.1$; $m / z$ (ESMS) $861\left(\mathrm{C}_{32} \mathrm{H}_{51} \mathrm{~N}_{8} \mathrm{O}_{4} \mathrm{EuClO}_{4}{ }^{2+}\right) 381\left(\mathrm{M}^{+} / 2\right)$; HRMS: $m / z$ (ESMS) Found: $762.3196 \mathrm{C}_{32} \mathrm{H}_{51} \mathrm{~N}_{8} \mathrm{O}_{4}$ Eu requires 762.3232. Found C 31.67, H 4.77, N 10.11. Expected C 32.10, H 4.23, N 9.63 $\mathrm{C}_{32} \mathrm{H}_{51} \mathrm{~N}_{8} \mathrm{O}_{4} \mathrm{Eu}^{3+} \cdot \mathrm{Na}^{+}\left(\mathrm{ClO}_{4}^{-}\right)_{4} \cdot \mathrm{CH}_{2} \mathrm{Cl}_{2} \cdot \mathrm{CH}_{3} \mathrm{CN}$.

\section{Eu(III) complex of ligand 3, Eu3}

A solution containing $\mathrm{Eu}\left(\mathrm{CF}_{3} \mathrm{SO}_{2}\right)_{3}(0.173 \mathrm{mg}, 0.246 \mathrm{mmol})$ and ligand $3(0.153 \mathrm{mg}, 0.246 \mathrm{mmol})$ in $\mathrm{CH}_{3} \mathrm{CN}\left(15 \mathrm{~cm}^{3}\right)$ was freezethawed twice and then heated at reflux overnight. After, the solution was left to cool to room temperature. The solution was then added dropwise to a swirling solution of ether and was then left for a further $30 \mathrm{~min}$. A precipitate formed. Ether was then removed and the resulting solid was dried under vacuum to yield Eu3 as a light yellow solid (0.1757 g, 91.7\%). Calculated for $\mathrm{C}_{42} \mathrm{H}_{54} \mathrm{~N}_{8} \mathrm{O}_{14} \mathrm{~S}_{3} \mathrm{~F}_{9}$ Eu: C, 38.35; H, 4.14; N, 8.52; Found: C, 30.44; $\mathrm{H}, 3.61 ; \mathrm{N}, 7.70 ; \delta_{\mathrm{H}}(400 \mathrm{MHz}, \mathrm{MeOH}) 31.92,10.87,8.69,7.74$, $5.04,3.39,1.3,0.17,-5.64,-7.56,-13.39,-15.65 ; \delta_{\mathrm{F}}(376 \mathrm{MHz}$, $\mathrm{MeOH}) 78.18$; Mass Spec (MeCN, ES+) $m / z$ Expected: 1224.12 Found: 1075.32 [M - triflate], 463.14 [M - 2triflate/2], 388.16 [M 3triflate/2]; IR $v_{\max } / \mathrm{cm}^{-1} 3470,1623,1510,1460,1437,1411,1256$, 1226, 1166, 1081, 1031, 958, 910, 824, 802, 781, 760, 639, 575, 517, 352.

\section{Eu(III) complex of ligand 4, Eu4}

Ligand 4 and $\mathrm{Eu}\left(\mathrm{CF}_{3} \mathrm{SO}_{3}^{-}\right)_{3}$ were added in a 1:1 ratio to $\mathrm{MeCN}$ $\left(15 \mathrm{~cm}^{3}\right)$. The solution was freeze-thawed twice and was then heated at reflux overnight while being stirred. After refluxing the solution was left to cool to room temperature. The solution was then added dropwise to a stirred solution of ether and was then left for a further $30 \mathrm{~min}$. A precipitate formed. The ether was decanted off and the resulting solid was dried under vacuum to yield Eu4 as a light yellow solid $(0.1757 \mathrm{~g}, 91.7 \%)$. $\delta_{\mathrm{H}}(400 \mathrm{MHz}$, $\mathrm{MeOH}) 28.12,8.29,7.39,6.93,6.54,4.90,3.49,3.32,2.77,2.29$, 2.04, 1.18, 0.97, 0.27, -1.99, -5.83, -7.76, -12.35, -13.39, -13.69; $\delta_{\mathrm{F}}(376 \mathrm{MHz}, \mathrm{MeOH})-80.54$; Mass Spec $(\mathrm{MeCN}, \mathrm{ES}+) \mathrm{m} / \mathrm{z}$ Expected: 1181.83, Found: 441.12 [M - 2triflate/2], 367.14 [M 3triflate/3]; IR $v_{\max } / \mathrm{cm}^{-1} 3318,3138,2953,2884,1639,1587,1513$, $1464,1417,1363,1255,1226,1166,1086,1030,994,972,936,893$, $831,806,794,781,761,723,639,575,517$.

\section{Acknowledgements}

We thank Trinity College Dublin for Postgraduate Studentships (to AMF and JPL), Enterprise Ireland PhD studentship support (JPL), IRCSET for IRCSET Postdoctoral Fellowship (to SEP) and Kinerton Ltd (now Ibsen Ltd.) for financial support.

\section{Notes and references}

1 C. M. G. dos Santos, A. J. Harte, S. J. Quinn and T. Gunnlaugsson, Coord. Chem. Rev., 2008, 252, 2512; J. P. Leonard, C. B. Nolan, F. Stomeo and T. Gunnlaugsson, Top. Curr. Chem., 2007, 281, 1-43; T. Gunnlaugsson and F. Stomeo, Org. Biomol. Chem., 2007, 5, 1999-2009; J. P. Leonard and T. Gunnlaugsson, J. Fluoresc., 2005, 15, 585.

2 J.-C. G. Bunzli, Acc. Chem. Res., 2006, 39, 53; S. Faulkner, S. J. A. Pope and B. P. Burton-Pye, Appl. Spectrosc. Rev., 2005, 40, 1.

3 S. Comby, F. Stomeo, C. P. McCoy and T. Gunnlaugsson, Helv. Chim. Acta, 2009, 92, 2461; A. S. Chauvin, S. Comby, B. Song, C. D. B. Vandevyver, F. Thomas and J. C. G. Bünzli, Chem.-Eur. J., 2007, 13, 9515; J.-C. G. Bunzli and C. Piguet, Chem. Soc. Rev., 2005, 34, 1048.

4 C. M. G. dos Santos, P. B. Fernandez, S. E. Plush, J. P. Leonard and T. Gunnlaugsson, Chem. Commun., 2007, 3389; C. S. Bonnet, M. Devocelle and T. Gunnlaugsson, Chem. Commun., 2008, 4552; K. Sénéchal-David, J. P. Leonard, S. E. Plush and T. Gunnlaugsson, Org. Lett., 2006, 8, 2727. 
5 K. Sénéchal-David, S. J. A. Pope, S. Quinn, S. Faulkner and T. Gunnlaugsson, Inorg. Chem., 2006, 45, 10040; B. McMahon, P. Mauer, C. P. McCoy, T. C. Lee and T. Gunnlaugsson, J. Am. Chem. Soc., 2009, 131, 17542.

6 L. Pellegatti, J. Zhang, B. Drahos, S. Villette, F. Suzenet, G. Guillaumet, S. Petoud and E. Toth, Chem. Commun., 2008, 6591; S. P. ClaudelGillet, J. Steibel, N. Weibel, T. Chauvin, M. Port, I. Raynal, E. Toth, R. F. Ziessel and L. J. Charbonniere, Eur. J. Inorg. Chem., 2008, 2856; C. S. Bonnet, F. P. Fries, A. Gadelle, S. Gambarelli and P. Delangle, J. Am. Chem. Soc., 2007, 129, 10401; X. Y. Chen, Y. Bretonniere, J. Pecaut, D. Imbert, J.-C. G. Bunzli and M. Mazzanti, Inorg. Chem., 2007, 46, 625.

7 A. Nonat, C. Gateau, P. H. Fries and M. Mazzanti, Chem.-Eur. J., 2006, 12, 7133; A. M. Nonat, S. J. Quinn and T. Gunnlaugsson, Inorg. Chem., 2009, 48, 4646; J. Massue, S. E. Quinn and T. Gunnlaugsson, J. Am. Chem. Soc., 2008, 130, 6900.

8 F. Liellar, G.-L. Law, E. J. New and D. Parker, Org. Biomol. Chem., 2008, 6, 2256; J. J. Yu, D. R. A. Poole, G. Bobba, M. J. Cann, J.-C. Frias, D. Parker and R. D. Peacock, Org. Biomol. Chem., 2005, 3, 1013.

9 C. P. Montgomery, B. S. Murray, E. J. New, R. Pal and D. Parker, Acc. Chem. Res., 2009, 42, 925; A. Thibon and V. C. Pierre, Anal. Bioanal. Chem., 2009, 394, 107; J. C. G. Bünzli, S. Comby, A. S. Chauvin and C. D. B. Vandevyver, J. Rare Earths, 2007, 25, 257; G. R. Motson, J. S. Fleming and S. Brooker, Adv. Inorg. Chem., 2004, 55, 361.

10 J. R. Morrow, T. L. Amyes and J. P. Richard, Acc. Chem. Res., 2008, 41, 539.

11 A.-M. Fanning, S. E. Plush and T. Gunnlaugsson, Chem. Commun., 2006, 3791; T. Gunnlaugsson and A. J. Harte, Org. Biomol. Chem., 2006, 4, 1572; T. Gunnlaugsson, R. J. H. Davies, P. E. Kruger, P. Jensen, C. S. Stevenson, S. Mulready and A.-M. Fanning, Tetrahedron Lett., 2005, 46, 3761; T. T. Gunnlaugsson, J. P. Leonard, S. Mulready and M. Nieuwenhuyzen, Tetrahedron, 2004, 60, 105.

12 T. Gunnlaugsson, M. Nieuwenhuyzen and C. Nolan, Polyhedron, 2003, 22, 3231; T. Gunnlaugsson, R. J. H. Davies, M. Nieuwenhuyzen, J. E. O'Brien, C. S. Stevenson and S. Mulready, Polyhedron, 2003, 22, 711.

13 D. Parker, R. S. Dickins, H. Puschmann, C. Cossland and J. A. K. Howard, Chem. Rev., 2002, 102, 1977; D. Parker, Coord. Chem. Rev., 2000, 205, 109; D. Parker and J. A. G. Williams, J. Chem. Soc., Dalton Trans., 1996, 3613.

14 R. Pal and Parker, Org. Biomol. Chem., 2008, 6, 1020; R. Pal and D. Parker, Chem. Commun., 2008, 474.

15 F. Stomeo, C. Lincheneau, J. P. Leonard, J. E. O'Brian, R. D. Peacock, C. P. McCoy and T. Gunnlaugsson, J. Am. Chem. Soc., 2009, 131, 9636; J. Massue, S. E. Quinn and T. Gunnlaugsson, J. Am. Chem.
Soc., 2008, 130, 6900; S. E. Plush and T. Gunnlaugsson, Dalton Trans., 2008, 3801; J. P. Leonard, P Jensen, T. McCabe, J. E. O'Brien, R. D. Peacock, P. E. Kruger and T. Gunnlaugsson, J. Am. Chem. Soc., 2007, 129, 10986; S. E. Plush and T. Gunnlaugsson, Org. Lett., 2007, 9, 1919; T. Gunnlaugsson, A. J. Harte, J. P. Leonard and M. Nieuwenhuyzen, Supramol. Chem., 2003, 15, 505.

16 M. Andrews, R. H. Laye, L. P. Harding and S. J. A. Pope, Polyhedron, 2008, 27, 2365; S. J. A. Pope, B. P. Burton-Pye, R. Berridge, T. Khan, P. J. Skabara and S. Faulkner, Dalton Trans., 2006, 2907.

17 S. J. A. Pope and R. H. Laye, Dalton Trans., 2006, 3108; D H. Tsukube and S. Shinoda, Chem. Rev., 2002, 102, 2389.

18 C. S. Bonnet and T. Gunnlaugsson, New J. Chem., 2009, 33, 1025; C. S. Bonnet, J. Massue, S. E. Quinn and T Gunnlaugsson, Org. Biomol. Chem., 2009, 7, 3074; C. P. McCoy, F. Stomeo, S. E. Plush and T. Gunnalugsson, Chem. Mater., 2006, 18, 4336; T. Gunnlaugsson, C. P. McCoy and F. Stomeo, Tetrahedron Lett., 2004, 45, 8403; T. Gunnalugsson, J. P. Leonard, K. Sénéchal and A. J. Harte, J. Am. Chem. Soc., 2003, 125, 12062; T. Gunnlaugsson, D. A. Mac Dónaill and D. Parker, J. Am. Chem. Soc., 2001, 123, 12866; T. Gunnlaugsson, D.A. Mac Dónaill and D. Parker, Chem. Commun., 2000, 93; T. Gunnlaugsson and D. Parker, Chem. Commun., 1998, 511.

19 M. Woods and A. D. Sherry, Inorg. Chem., 2003, 42, 4401; M. Woods, G. E. Kiefer, S. Bott, A. Castillo-Muzquiz, C. Eshelbrenner, L. Michaudet, K. McMillan, S. D. K. Mudigunda, D. Ogrin, G. Tircso, S. Zhang, P. Zhao and A. D. Sherry, J. Am. Chem. Soc., 2004, 126, 9248; P. Lowe and D. Parker, Chem. Commun., 2000, 707; M. P. Lowe and D. Parker, Inorg. Chim. Acta, 2001, 317, 163; D. Parker, K. Senanayake and J. A. G. Williams, Chem. Commun., 1997, 1777; A. P. de Silva, H. Q. N. Gunaratne and T. E. Rice, Angew. Chem., Int. Ed. Engl., 1996, 35, 2116.

20 M. P. Lowe, D. Parker, O. Reany, S. Aime, M. Botta, G. Castellano, E. Gianolio and R. Pagliarin, J. Am. Chem. Soc., 2001, 123, 7601.

21 R. Kataky, K. E. Matthes, P. E. Nicholson, D. Parker and H. J. Buschman, J. Chem. Soc., Perkin Trans. 2, 1990, 1425; L. Carlton, R. D. Hancock, H. Maumela and K. P. Wainwright, J. Chem. Soc., Chem. Commun., 1994, 1007.

22 A. Beeby, D. Parker and J. A. Gareth, J. Chem. Soc., Perkin Trans. 2, 1996, 1565; L. Alderighi, A. Bianchi, L. Calabi, P. Dapporto, C. Giorgi, P. Losi, L. Paleari, P. Paoli, P. Rossi, B. Valtancoli and M. Virtuani, Eur. J. Inorg. Chem., 1998, 1581; S. Aime, A. Barge, J. I. Bruce, M. Botta, J. A. K. Howard, J. M. Moloney, D. Parker, A. S. De Sousa and M. Woods, J. Am. Chem. Soc., 1999, 121, 5762.

23 S. E. Plush, S. F. Lincoln and K. P. Wainwright, Dalton Trans., 2004, 1410. 